\title{
Sustainability Reports Based on XBRL through a Service-Oriented Architecture Approach
}

\author{
Edson Mota, Daniela Costa, Paulo Caetano da Silva \\ Masters program in Systems and Computer Science, Salvador University (UNIFACS), Salvador-BA, 41820-460. Brazil
}

\begin{abstract}
The practice of disclosure of information on corporate sustainability represents a breakthrough in relations between business and society. The initiative of the Global Reporting Initiative (GRI) in the adoption of XBRL in the process of dissemination of sustainability reporting contributes to the increase of their quality; however, the great heterogeneity of enterprise information systems still pose an obstacle to their use in the corporative scenario. This article presents a conceptual model for the adoption of a serviceoriented architecture for issuing reports based on XBRL taxonomy proposed by GRI in supporting the processes of disclosure of sustainability information.
\end{abstract}

Keywords-disclosure; sustainability; global reporting initiative; SOA; XBRL.

\section{INTRODUCTION}

The discussion on sustainable development, predominant in recent decades, has brought to light new challenges faced by businesses and markets. Organizations disclose information regarding their social, environmental and economic positioning, through sustainability reports and this unified vision of the sustainable overall situation of businesses begins to influence stakeholders in regard to how organizations position themselves and their actions in the social reality in their surroundings.

The Global Reporting Initiative (GRI) [1] is a nongovernmental organization founded in 1997 as a joint initiative between the Coalition for Environmentally Responsible Economics (CERES) [2] and the United Nations Environment Programme (UNEP) [3]. Among its key initiatives is the definition of a standardized model for the preparation of sustainability reports.

From its third generation of guidelines (GRI-G3), it was proposed to use the markup language eXtensible Businesses Reporting Language (XBRL) [4] for the disclosure of information on the sustainability of organizations. Although this action represents a significant advance in relation to the analysis and use of information, the vast heterogeneity of enterprise systems that permeate organizations still represent a barrier to their adoption, since bringing together a wide range of information held in different systems and formats distributed by the company may not be trivial. With this approach, the adoption of a service-oriented architecture (SOA) is proposed as a way to mitigate the challenges related to the integration of systems, using the XBRL language to ensure the semantic nature of the highlighted information.
Besides the introduction, this paper is divided as follows: Section 2 presents a review of related literature. In Section 3 some barriers to the adoption of XBRL in the business scenario are discussed. In Section 4, an SOA-XBRL conceptual model is specified, focusing on the GRI, and finally, in Section 5, the conclusions are presented. In Section 6 the references used in this work are presented.

\section{LITERATURE REVIEW}

This section discusses some related work involving the use of SOA and XBRL technologies in processes of disclosure and information integration.

\section{A. The challenges of heterogeneity in business information systems}

In the work of [5], it was sought to identify the positive impacts on the adoption of XBRL in the context of business accounting, finding in this language, a way of mitigating the relevant issues on integration, organization and accounting information.

The work [6] corroborates this analysis referencing the advances related to continuous auditing in real time. In this work, a generic model to support the audit process based on a service-oriented architecture is proposed. Similarly, the work of [7] emphasizes the discussion of the integration of SOA and XBRL technologies, in this paper the authors propose a conceptual model in order to provide greater adaptability to changes in requirements, whether for legal or regulatory reasons. The authors seek to provide greater flexibility to change and, concomitantly, promote greater alignment with business processes that promote financial reporting.

Therefore, it is observed that the adoption of SOA and XBRL discussed in the related work, while keeping its focus on the financial transactions, provides great opportunities for the use in other scenarios. In the field of sustainability or environmental audits, it is possible to observe great similarity.

\section{B. Disclosure of Economic and Socio-Environmental Balance}

In [8] the authors argue about the factors and social motivations that have led companies to disclose, in addition to account balance, their sustainability performance. In [9], it was cited that companies have adopted environmental management strategies both for reasons related to government regulation as matters relating to global 
competitiveness. Other authors corroborate this understanding [10], for them the public started to ask more about the role of business in society, motivating changes in areas such as enterprise accounting, which started to show, in addition to economic information, socio-environmental issues. The authors [8] apud [11] define the social balance as: "A management and information tool that aims to demonstrate, in the most transparent possible way, financial, economic, environmental and social information." Despite being a management tool, the social balance is less comprehensive than the sustainability report. In general, sustainability reports cover best practices for sustainable management [8]. The GRI [1] defined the sustainability report as "a balanced and reasonable representation of the sustainability performance of the organization, including positive and negative contributions." In [12] it is stated that: "Of all the organizations which provide guidelines on environmental management or generation of environmental information, this is what seems most complete and comprehensive with their guidelines." For [8], two factors contribute to this statement: the first consists in the fact that it is prepared for different stakeholders, and the second, because it is a methodology based on triple-bottom-line concepts (TBL) [13], and deals with social, environmental and economic dimensions in an interdependent way.

The disclosure of sustainability information has raised the interest of researchers in building models for the adequacy of procedures proposed by GRI in the corporate setting. In this context, the adoption of XBRL markup language makes important contributions [14], [15].

\section{THE CHALLENGES IN THE ADOPTION OF XBRL FOR} THE DISCLOSURE OF SUSTAINABILITY REPORTS GRI

For Scott Leibs [16], the adoption of XBRL by GRI provides greater ease in the collection and analysis of sustainability data, besides influencing the improvement of the quality of data that make up the report [16]. Figure 1 shows the elements that make up the process of dissemination of GRI reports and how the adoption of XBRL is inserted in this context [17].

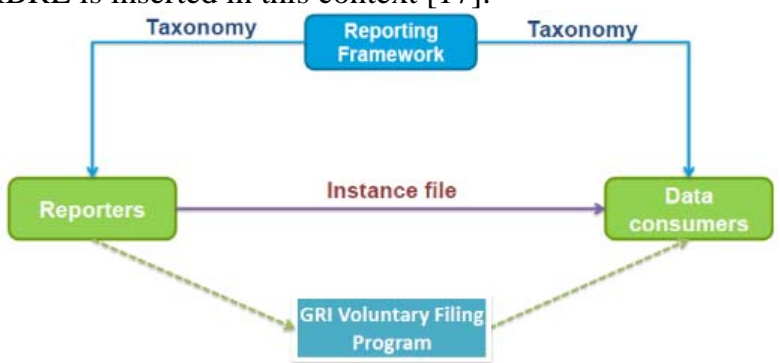

Figure 1. Conceptual representation relating XBRL and GRI [17]

It is observed that the process of disclosure of information is intermediated by XBRL. The understanding of the content of the report is preserved in the common taxonomy used by the elements involved in this transaction. Silva comments that the functionality of XBRL is based on the interrelationship of three components, which are: taxonomy, the instance of the document and the style sheet, the latter being a complement to the first two [18]. Moreira defines taxonomy as: "a dictionary to provide standard definitions for financial reporting information" [19]. The document instance is the XBRL component that covers the facts to be reported, its structure consists of a set of elements that converge to create a unified standard for exchanging information. Figure 2 depicts the proposed model by XBRL International Inc. [20]

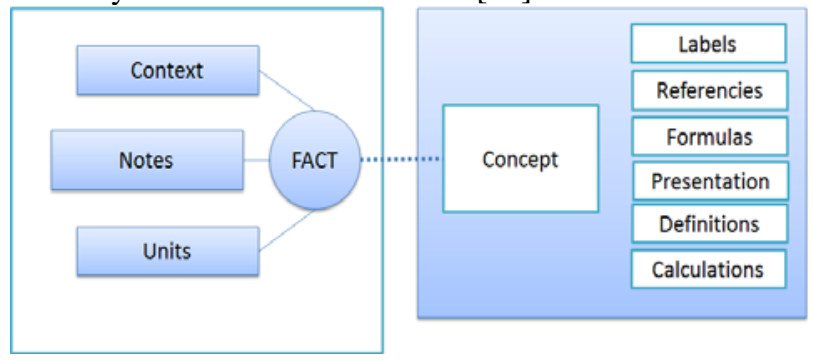

Figure 2. Simplified structure of the taxonomy and XBRL instance documents (adapted of HOFFMAN, C.; WATSON, 2010)

If on one hand XBRL contributes to the disclosure of information through the semantic organization of their data of sustainability, on the other hand, the great heterogeneity and dissemination of business information pose new challenges for their integration, resulting in the realization of large integrations, or long routines for the extraction of information.

An alternative to mitigate the problems may be the use of standardized services to the information exchange. The authors [21] define service as "A kind of relationship (contract) between a provider and a consumer." About the services creation, a combination of technologies can be used, among which the Web Services stand out with highly relevance. According to Marzullo, the Web Services represent the convergence of some technologies [22], which must work synergistically in the construction and collaboration of the developed services. In the next section, a model is proposed in order to simplify the integration scenarios and the disclosure of sustainability information.

IV. SOA-XBRL INTEGRATION MODEL FOR THE CONSTRUCTION OF SUSTAINABILITY REPORTS BASED ON GRI

The proposed model is divided into five layers, plus two conceptual layers: (1) Infrastructure integration, which aims to promote the access and retrieval of information within the information structure of the company and (2) Global Reporting Initiative, which seeks to integrate the architecture proposed by the GRI for the informational scenario of the organization. Figure 3 presents the proposed model using SOA, XBRL, and GRI. 


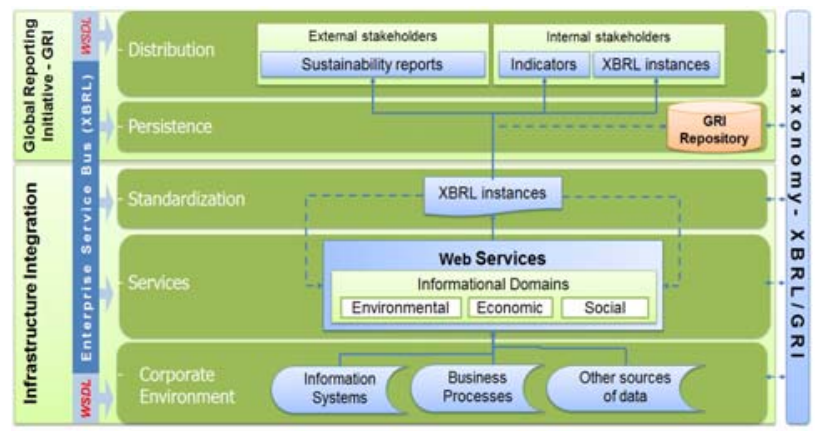

Figure 3. Model of services, XBRL and GRI to support sustainability reports

Enterprise Service Bus (ESB) or service bus is permeating all layers of the model. Its function in the model is to provide access to resources provided by the service layer. For Marzullo, this type of configuration produces advantages in situations in which the need for integration is imminent. [22]. Each ESB entry interconnects layers through a WSDL (Web Service Description Language) [23] interface, which is designed to describe the service, offering details about its features and functionality. About XBRL/ GRI taxonomy, its share in the exchange of messages between layers should ensure standardization of information throughout all processes of disclosure. Subsequently, the other layers that make up the proposed model are described in detail:

(1) Corporate Environment Layer: Here it is sought to define the systems that store information directly or indirectly related to the scope of the sustainability of the enterprise. It is understood as the scope of sustainability, the set of information required in accordance with the dictates proposed in the body of the Global Reporting Initiative guidelines. This step must start with a mapping of enterprise information systems, examining their characteristics, technological aspects and mainly the domain to which each software application is directed. The results of this mapping reveal the systems that should be part of the integration process, assuming this set of data and systems as requirements of service-oriented architecture proposed in this paper.

(2) Services Layer: In this layer it is sought to gather the necessary services for the integration process. Basically, they are responsible for collecting the information distributed in the corporate environment, bringing them together and turning them into the XBRL format.

The services are materialized in the form of Web Services, which are scheduled to meet integration requirements needed for the construction of the interactive environment for the selection and retrieval of sustainability information. The model seeks to maintain its focus on informational domains defined in the conceptual sub layer located in the service layer, i.e. a set of services should always be connected to at least one informational domain, so that the provision of services enhances cohesion in the relationship among areas, services and the low coupling, inherent in the technologies based on Web Services.
(3) Standardization Layer: This layer loads the XBRL instance document with the recovered data in the corporate environment. The information is organized and retrieved from the taxonomy proposed by GRI, creating the XBRL instance document.

This process results in the instance of the document that contains the data that portray the sustainability performance of the organization. The XBRL instance document will then be available for storage and consumption.

(4) Persistence Layer: Composed of a repository called Repository GRI, this layer has the function of storing reports monitoring the organization's sustainability. Fundamentally, it is expected that this repository will not only allow fast retrieval of current information and stories about specific reports, but also enable the analysis, enabling the development of queries that permeate the various instances of documents stored, contributing to performing complex analysis such as data mining and trend analysis, as a way to support decisions based on sustainability performance.

(5) Distribution Layer: This layer is conceptually divided into two categories: (1) internal stakeholders: This category seeks to gather, based on the body of knowledge and guidelines proposed by the GRI, the means for continuous monitoring of sustainability indicators through two aspects: (i) Indicators, which consist in the selection and retrieval of information available from previous layers and (ii) XBRL Instances, which enable easy integration of this information with other information systems of the organization or external systems; (2) External stakeholders: In this category, two XML formats may be used to facilitate the reading and analysis of information from different types of external consumers: (i) XBRL and (ii) XML adapted to the user's needs. The disclosures in XBRL format will provide ample support systematization, integration and use of the information reported. The XML format will enable the realization of simplified analyses, ensuring that users with limited computing resources based on XBRL can get quick access to information through a format adapted to their needs. For these cases, the distribution layer should receive instances of XBRL documents and pass them on to the style, whose function is to model information to XML format.

\section{V.CONCLUSION}

This paper aimed, through a service-based architecture integrated with XBRL, to contribute to building a model to simplify the processes of selection and disclosure of information about the sustainability performance of organizations. This structure allows to perform continuous monitoring of sustainability indicators, increasing the organization's ability to remain aligned to their social performance in, environmental and economic dimensions, whereas it integrates, through a technological framework involving SOA and XBRL, the fundamental dimensions of corporate sustainability, building a scale model that grows as the organization seeks to establish excellence in sustainability, internationalization and standardization of information. 
For future works, it is aimed to develop the degree of detail of the layers with the definition of a methodology for implementation and execution of the model proposed, as well as conducting a case study, in order to ensure the compliance of the proposed technologies in the scenario of sustainable management of organizations.

\section{REFERENCES}

[1] GRI, Directrizes para a Elaboração de Relatórios de Sustentabilidade (C) 2000-2006. Amsterdam, 2006.

[2] CERES, “CERES - Coalition for Environmentally Responsible Economies,” 2014. [Online]. Available: http://www.ceres.org/aboutus. [Accessed: 15-Mar-2014].

[3] UNEP, "UNEP - United Nations Environment Programme," 2014 [Online]. Available: http://www.unep.org/About/. [Accessed: 15Mar-2014].

[4] XBRL International., "XBRL. Extensible Business Reporting Language (XBRL) Specification,” 2003. [Online]. Available: http://specifications.xbrl.org/specifications-full-index-bystatus.html\#REC. [Accessed: 25-Mar-2014].

[5] H. Ascenção, I. Souza, and E. Souza, "XBRL (EXTENSIBLE BUSINESS REPORTING LANGUAGE), PARADOXO PARA O MERCADO GLOBALIZADO,” Portal da Classe Contábil. [Online]. Available:

http://www.classecontabil.com.br/site/trabalhos/TecnologiadaInform acaonaLinguagemXBRL1.pdf. [Accessed: 18-Feb-2014].

[6] H. Ye, S. Chen, and F. Gao, "On application of SOA to continuous auditing,” WSEAS Trans. Comput., vol. 7, no. 5, pp. 532-541, May 2008

[7] J. R. P. Moreira and P. C. Da Silva, "Soa and Xbrl: Soa Model Implementation and Integration With Xbrl," Proc. 10th CONTECSI Int. Conf. Inf. Syst. Technol. Manag., pp. 3863-3883, Jun. 2013.

[8] L. F. Ferreira, G. E. Garcia, F. J. B. Junior, and D. D. M. Ferreira, "Indicadores de Sustentabilidade Empresarial : uma comparação entre os indicadores do balanço social IBASE e relatório de sustentabilidade segundo as diretrizes da global reporting initiative," pp. 1-15, 2006.

99] P. S. Wisner, M. J. Epstein, and R. P. Bagozz, "ORGANIZATIONAL ANTECEDENTS AND CONSEQUENCES
OF ENVIRONMENTAL PERFORMANCE,” Adv. Environ. Account. Manag., vol. 3, 2006

[10] L. Aligleri, L. A. Aligleri, and I. Kruglianskas, GESTÃO SOCIOAMBIENTAL: Responsabilidade e Sustentabilidade do Negócio, 1st ed. São Paulo: Atlas, 2009, p. 248.

[11] J. E. P. Tinoco and M. E. P. Kraemer, CONTABILIDADE E GESTÃO AMBIENTAL. São Paulo: Atlas, 2004, p. 296.

[12] V. Nossa, "DISCLOSURE AMBIENTAL : UMA ANÁLISE DO CONTEÚDO DOS RELATÓRIOS AMBIENTAIS DE” FEA/USP Tese de Doutorado, São Paulo, 2002.

[13] J. Elkington, Cannibals with forks: the triple bottom line, 21st ed. Oxford: New Society Publishers, 1998.

[14] J. Baumunk, "Sustainability Reporting and XBRL," SSRN - Soc. Sci. Res. Netw., 2009.

[15] H. Arndt, R. Isenmann, J. Brosowski, I. Thiessen, and J. Marx-gomez, "Sustainability Reporting Using the eXtensible Business Reporting Language ( XBRL ),” pp. 1-8, 2006.

[16] S. Leibs, "Sustainability reporting: Earth in the balance sheet," CFO, 2007. [Online]. Available: http://www.cfo.com/article.cfm/10234097. [Accessed: 21-Jan-2014].

[17] N. Arbex, "Modernizing Sustainability Reporting - GRI , G4 and XBRL -," 24th XBRL International Conference, 2012. [Online]. Available: http://archive.xbrl.org/24th/sites/24thconference.xbrl.org/files/CAPM 7ArbexXBRL financial-market-symposium-march 2012.pdf. [Accessed: 18-Feb-2014].

[18] P. C. Silva, "O papel de XBRL na harmonização de normas contábeis,” in Workshop Brasileiro de XBRL, 2005.

[19] O. Moreira, "O XBRL no Brasil: um estudo empírico com as empresas de capital aberto,” Programa de Pós-Graduação em Ciências Contábeis. USP, São Paulo, 2005.

[20] L. A. Hoffman, C.; Watson, XBRL for Dummies. 2010.

[21] L. J. Zhang, J. Zhang, and H. Cai, Services Computing. Beijing: Springer, 2007.

[22] F. P. Marzullo, SOA na Prática Inovando o seu negócio por meio de soluções orientadas a serviço. Novatec, 2009.

[23] W3C, “WSDL," W3C, 2007. [Online]. Available: http://www.w3.org/standards/techs/wsdl\#w3c_all. [Accessed: 21Jan-2014]. 